\title{
Antibacterial Studies of Essential Oil and Different Extract Fractions from the Seeds of Nigella sativa $L$.
}

\author{
Khuder D. Sulayman \\ Department of Biology, College of Education, University of Mosul \\ Mosul-Iraq
}

$\begin{array}{lr}\text { Received } & \text { Accepted } \\ 2006 / 7 / 17 & 2006 / 4 / 26\end{array}$

الملخص

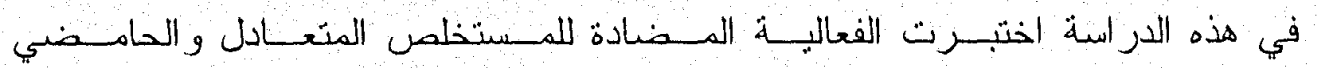

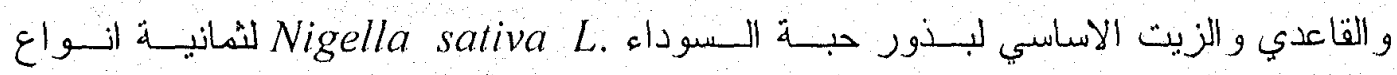
Proteus mirabilis و Bacillus subtilis , Staphylococcus aureus من البكتريـ Pseudomonas aeruginosa, Escherichia coli , Salmonella typhi, و Shigella flexneri و Salmonella typhimurium وقد استعطل المضادين الحيويين Amoxicillin و Gentamycin

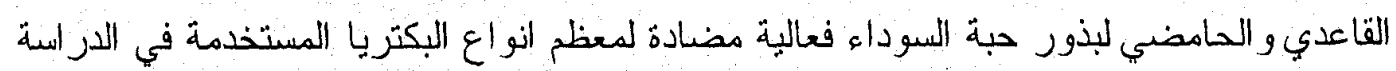
وخصوصا Salmonella typhimurium , Salmonella typhi , Shigella flexneri)

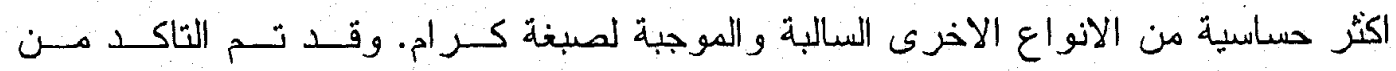

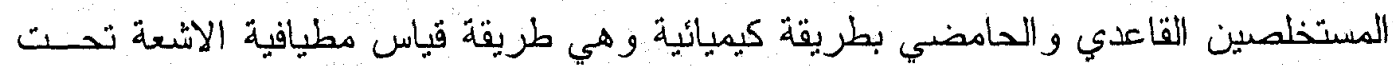
الحمر اء (IR spectroscopy).

\section{ABSTRACT}

The antibacterial activity of the neutral, acidic, basic fractions and essential oil of Nigella sativa seeds were tested for their in vitro activity against eight species of bacteria, Staphylococcus aureus, Bacillus subtilis, Proteus mirabilis, Salmonella typhi, E. coli, Pseudomonas aeruginosa, Salmonella typhimurium and Shigella flexneri were investigated and compared with standard antibiotics Gentamycin and Amoxicillin.

The results indicate that these essential oil, acidic and basic fractions have antibacterial activity against most of the tested bacteria. We 
conclude from the above results, that the essential oil, acidic and basic fractions seeds of Nigella sativa have antibacterial activity against gram negative bacterial especially (Sal. typhimurium, Sal. typhi and Sh. flexneri) more than other gram negative and gram positive bacteria. The acidic and basic fractions compounds were confirmed spectrochemically by using the IR spectroscopy.

\section{INTRODUCTION}

Nigella sativa (black cumin) is an annual herbaceous plant growing in Western Asia and the Mediterranean region for its seeds. The seeds contain $40 \%$ volatile oil (1). The seeds of Nigella sativa have been used traditionally for centuries in the Middle East, Northern Africa and South Asia for the treatment of various diseases $(2,3)$.

The plant extracts and essential oil showed a broad range of pharmacological effects such as antidiabetic $(4,5)$, spasmolytic and bronchodilator $(6,7)$, analgesic and anti-inflammatory (8). The extracts also showed in vitro and in vivo antibacterial effects (9). We decided to study the effects of neutral, acidic, basic fraction and essential oil from extracts of the Nigella sativa seed on some pathogenic bacterial strains.

\section{MATERIALS AND METHODS}

A. Plant material. Nigella sativa seeds were obtained from local market in Mosul city.

B. Preparation of crude extract. $150 \mathrm{gm}$ of the powdered dried seeds of Nigella sativa were used for the preparation of the aqueous extract $(10,11,12)$.

C. Extraction. We have separated three major fractions namely, neutral $(\mathrm{N})$, acidic (A) and basic (B) from the aqueous extract of Nigella sativa seeds as indicated in Scheme 1.

D. Bacteria. The bacteria species used are listed in Table (1). All strains were obtained from Biology Department, College of Science, University of Mosul. Then growth up to the stationary phase in a nutrient broth at $37^{\circ} \mathrm{C}$ and a sample of $0.5 \mathrm{ml}$ of each bacteria was spread over a surface of a Muller-Hinton agar plate (13).

E. Antibacterial assay. Discs of filter paper, $6 \mathrm{~mm}$ in diameter, were sterilized at $140{ }^{\circ} \mathrm{C}$ for $1 \mathrm{~h}$. and impregnated with $1 \mathrm{ml}$ of stock solution of $10 \mathrm{mg} / \mathrm{ml}$ of each fraction and then dried. Distilled water was used as a solvent for the three fractions and dimethyl sulfoxide (DMSO) for the antibiotics and ethylene glycol for essential oil. The inoculated plates were incubated at $37^{\circ} \mathrm{C}$ for $18 \mathrm{~h}$ and the inhibition zones were measured. 


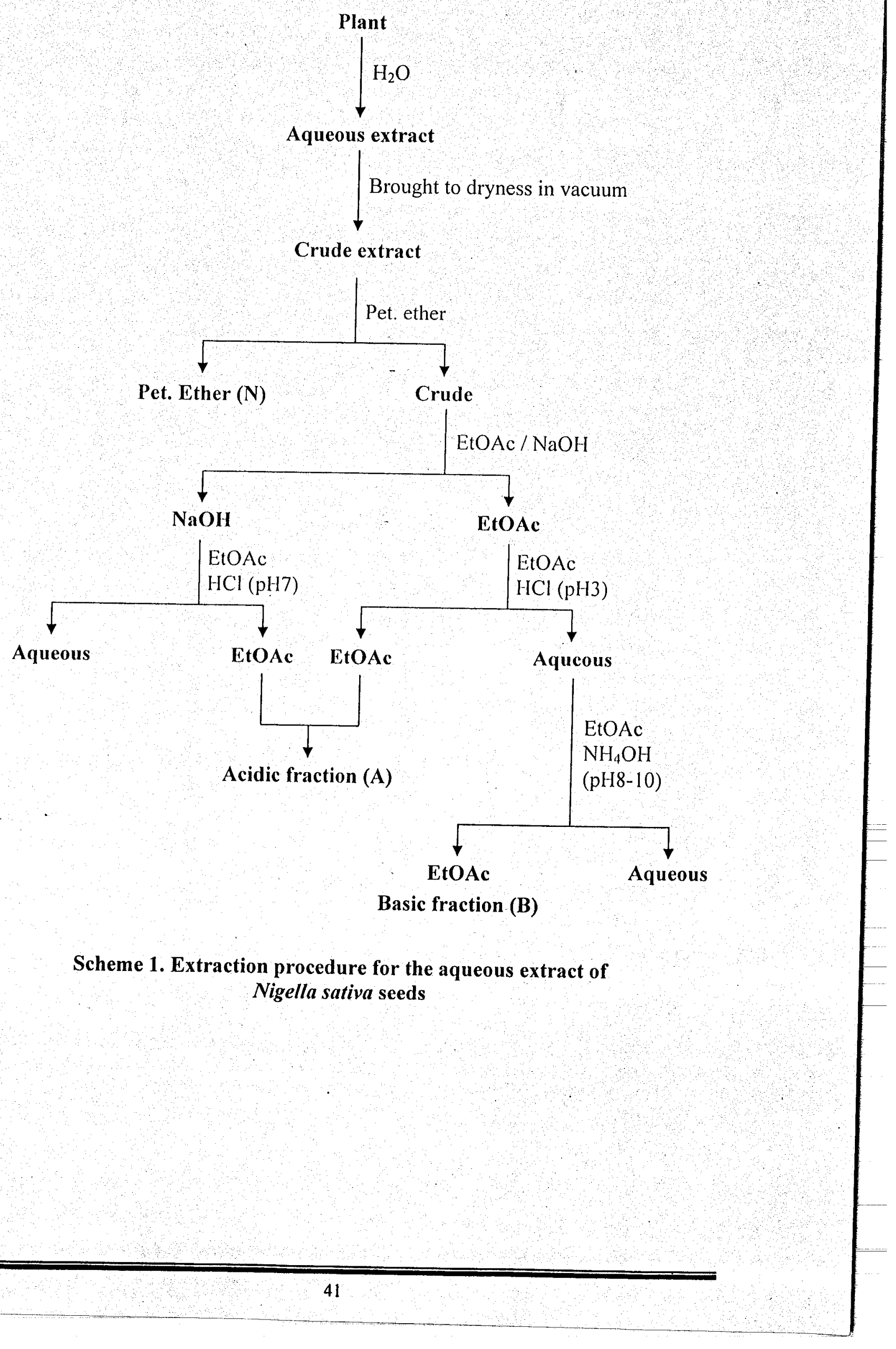


F. a. Preparation of Nigella sativa seeds oil. The Nigella sativa seeds oil was prepared according to reported procedure (Khodair et al., 1993 ) by grinding $50 \mathrm{gm}$ of the seeds in $250 \mathrm{~cm}^{3}$ of ethyl alcohol $(95 \%)$ in the grinder in side an ice-bath. Shake the mixture by electrical shaker for $1 \mathrm{hr}$ at room temperature filter the suspension through many layers of gauze then through the filtration funnel to get rid from the hard residue. Centrifuge the filtrate with speed of $(1000 \mathrm{xg})$ for 15 minutes. Then collect the oily layer which composed of the oil of the seeds.

b. Steralization of Nigella sativa seeds oil. $1 \mathrm{~cm}^{3}$ of the oil dissolved in $9 \mathrm{~cm}^{3}$ of ethylene glycol then sterilized by using filter membrane $(0.22$ micron $)$. The sterilized oil used for further dilution used in the experiments.

G. Test of isolation compounds:

a. Alkaloids test (basic fraction). Myers test was used to identified the alkaloids, we mixed $5 \mathrm{ml}$ from sample with drops from the reagent, then we showed white precipitate, that is positive result of alkaloids test (15).

b. Acids test. lodate-idide test was used to identified the acids, we added 2 drops from $2 \%$ potassium iodide to the sample and 2 drops from $4 \%$ potassium iodate, after boiling the mixture for 1 minute, added drops from starch solution, then we showed blue colour which referred positive result of acid test (16).

H. Identification of isolation compounds. Identified the isolation compounds by used the infrared (IR) by used the infrared spectrophotometer model Tensor 27 Bruker Co., Germany (17).

\section{RESULTS AND DISCUSSION}

The investigation of the acidic and basic extract and the basic oil of the Nigella sativa seeds showed different effects against the bacterial including Staph. aureus, Sal. typhi, P. mirabilis, B. subtilis, Ps. aeruginosa, Sh. Flexneri, Sal. typhimurium which used in the present study as shown in Table (1).

The neutral fraction study did not show any effect against bacteria used in the present study. As well the acidic and basic extracts with basic oil showed no effect against $B$. subtilis and $P$ s. aeruginosa (Table 1). The basic oil showed almost similar inhibition effect against both bacteria S. typhimurium, $S$. typhi and Sh. flexneri compared with the standard antibiotic Gentamycin, and high inhibition effect compared with the Amoxicillin so the diameter of the inhibition zone at the concentration 0.1 $\mathrm{cm}^{3} / \mathrm{cm}^{3}$ was $22 \mathrm{~mm}$, while the diameter of the inhibition zone of the antibiotic at concentration $10 \mathrm{mg} / \mathrm{cm}^{3}$ was $21 \mathrm{~mm}$. the acidic extract for the N.S. seeds showed less effect compared with basic oil against the 
bacteria mentioned above. So, the diameter of the inhibition zone at concentration $10 \mathrm{mg} / \mathrm{cm}^{3}$ for the bacteria Sal. typhimurium was $19 \mathrm{~mm}$, while the effect of acidic extract against the Sal. typhimurium were more than that for the standard antibiotics Gentamycin and Amoxicillin $(18,19)$. The effect of the basic extract against those bacteria mentioned above were less than that for both the basic oil and the acidic extract. The examination results showed that the effect of the basic oil and both extracts against the Staph. aureus, E. coli and Pr. Mirabilis were less than that for the other types of bacteria as shown in Table (1). This was further supported by other researchers $(20,21,22)$ in their studies of the basic oil and both, the acidic and basic extracts against the gram positive and gram negative bacteria. We could conclude from this study that the gram negative bacteria were more sensitive toward the basic oil and the both extracts except the Pseudo. aeruginosa. Meanwhile, the Sal typhimurium and Sh. flexnai were the most sensitive bacteria toward the extracts and this was in accordance with many studies (23).

The extracted compounds were confirmed spectrochemically by using the IR spectroscopy. The absorption of infrared spectroscopy (IR) gave absorption of stretching for $(\mathrm{O}-\mathrm{H})$ and $(\mathrm{N}-\mathrm{H})$ bands between (3300$3550) \mathrm{cm}^{-1}$. It showed absorption of $(\mathrm{C}-\mathrm{H})$ bonds stretching at $2855 \mathrm{~cm}^{-1}$ and $2927 \mathrm{~cm}^{-1}$, so gave absorption of $(\mathrm{C}=\mathrm{O})$ bond stretching at $1724 \mathrm{~cm}^{-1}$, $(\mathrm{C}=\mathrm{N})$ bond stretching at $1654 \mathrm{~cm}^{-1},(\mathrm{~N}-\mathrm{H})$ bond bending at $1557 \mathrm{~cm}^{-1}$, (C-O) bond bending at $1100 \mathrm{~cm}^{-1},(\mathrm{C}-\mathrm{H})$ bond bending at $784 \mathrm{~cm}^{-1}$. These all absorptions refer to that these compounds have alkaloidic properties (Figure 1).

The absorption of infrared spectroscopy (IR) showed that these isolated compounds have acidic organic properties which gave absorption at $1446 \mathrm{~cm}^{-1}$ ascribe to $(\mathrm{C}=\mathrm{O})$ bond, so gave a broad absorption range (3300-3600) $\mathrm{cm}^{-1}$ ascribe to carboxylic hydroxyl (OH). They showed absorption of (C-O) bond bending between (1004-1250) $\mathrm{cm}^{-1}$ as to aromatic system showed absorptions between $(1464-1558) \mathrm{cm}^{-1}$ acidic (Figure 2). 
Table (1): Antibacterial activity of the basic, acid and essential oil of Nigella sativa seeds against tested bacteria. Diameter of inhibition zone ( $\mathrm{mm}$ )

\begin{tabular}{|c|c|c|c|c|c|c|c|c|c|c|c|c|c|c|c|c|c|c|c|c|c|c|c|}
\hline \multirow{3}{*}{$\begin{array}{c}\text { Microorgan } \\
\text { isms }\end{array}$} & \multicolumn{12}{|c|}{ Concentration $(\mathrm{mg} / \mathrm{ml})$} & \multirow{2}{*}{\multicolumn{4}{|c|}{ 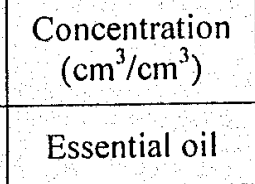 }} & \multirow{2}{*}{\multicolumn{4}{|c|}{$\frac{\begin{array}{c}\text { Control } 1 \\
\mathrm{mg} / \mathrm{ml}\end{array}}{\text { Amoxicillin }}$}} & \multirow{2}{*}{\multicolumn{3}{|c|}{$\frac{\text { Control } 2}{\mathrm{mg} / \mathrm{ml}}$}} \\
\hline & \multicolumn{4}{|c|}{$\begin{array}{c}\text { Basic } \\
\text { fraction }\end{array}$} & \multicolumn{4}{|c|}{$\begin{array}{l}\text { Acidic } \\
\text { fraction }\end{array}$} & \multicolumn{4}{|c|}{$\begin{array}{l}\text { Neutral } \\
\text { fraction }\end{array}$} & & & & & & & & & & & \\
\hline & $\begin{array}{l}1 \\
0\end{array}$ & 1 & 0. & $\begin{array}{c}0.0 \\
1\end{array}$ & 0 & 1 & $\begin{array}{l}0 . \\
1\end{array}$ & $\begin{array}{c}0.0 \\
1\end{array}$ & $\begin{array}{l}1 \\
0\end{array}$ & 1 & 0.0 & 0.0 & 0. & $\begin{array}{c}0.0 \\
6\end{array}$ & \begin{tabular}{|c|}
0.0 \\
5 \\
\end{tabular} & $\begin{array}{c}0.0 \\
4 \\
\end{array}$ & $\begin{array}{l}1 \\
0 \\
\end{array}$ & \begin{tabular}{l|l}
0 \\
1 & 1 \\
\end{tabular} & \begin{tabular}{l|l}
. & 0. \\
1 & 1 \\
\end{tabular} & 10 & \begin{tabular}{l|l}
1 & 1 \\
0 & 1 \\
\end{tabular} & 1 & $\begin{array}{c}0.0 \\
1\end{array}$ \\
\hline $\begin{array}{l}\text { Staph. } \\
\text { aureus }\end{array}$ & 1 & 7 & - & 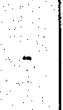 & 3 & 8 & - & - & - & - & - & - & 14 & 10 & - & - & $\begin{array}{l}2 \\
5\end{array}$ & \begin{tabular}{l|l}
1 \\
8
\end{tabular} & 48 & 8 & 1 & - & - \\
\hline B. subtilis & - & - & - & - & - & - & - & - & - & - & - & - & - & - & - & - & 1 & 1 & - & - & \begin{tabular}{l|l}
1 & 7 \\
3 &
\end{tabular} & $7-$ & - \\
\hline $\begin{array}{l}\text { Pr } \\
\text { mirabilis }\end{array}$ & $\begin{array}{l}1 \\
2\end{array}$ & 8 & - & - & $\begin{array}{l}1 \\
3\end{array}$ & 1 & 7 & - & - & - & - & - & 13 & 8 & - & - & $\begin{array}{l}1 \\
0\end{array}$ & 7 & - & 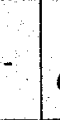 & \begin{tabular}{l|l}
1 & 1 \\
6 & 0
\end{tabular} & - & - \\
\hline Sal typhi & $\begin{array}{l}1 \\
6\end{array}$ & $\frac{1}{2}$ & 8 & - & $\begin{array}{l}1 \\
7\end{array}$ & $\begin{array}{l}1 \\
4\end{array}$ & 10 & - & - & - & - & - & 21 & 17 & 10 & 7 & $\begin{array}{l}1 \\
3\end{array}$ & 8 & - & . & \begin{tabular}{l|l}
2 & 1 \\
0 & 7
\end{tabular} & 12 & 27 \\
\hline E. coli & $\begin{array}{l}1 \\
4\end{array}$ & 1 & 8 & - & $\begin{array}{l}1 \\
5\end{array}$ & 3 & 10 & - & - & - & - & - & 15 & 11 & 7 & - & $\begin{array}{l}1 \\
2\end{array}$ & $7=$ & - & - & \begin{tabular}{l|l}
1 & 1 \\
9 & 3
\end{tabular} & 7 & - \\
\hline $\begin{array}{l}\text { Ps. } \\
\text { aeruginosa }\end{array}$ & - & - & - & - & - & - & - & - & - & - & - & - & - & - & - & - & - & - & - & - & -1. & $-1-$ & - \\
\hline $\begin{array}{l}\text { Sal. } \\
\text { typhimuriu } \\
m\end{array}$ & $\begin{array}{l}1 \\
7\end{array}$ & $\begin{array}{l}1 \\
3\end{array}$ & 10 & - & $\begin{array}{l}1 \\
9\end{array}$ & $\begin{array}{l}1 \\
5\end{array}$ & 12 & 8 & - & - & - & - & 23 & 18 & 13 & 7 & $\begin{array}{l}1 \\
3\end{array}$ & 8 & - & - & \begin{tabular}{l|l}
2 \\
1
\end{tabular} & \begin{tabular}{l|l}
1 & 8
\end{tabular} & \\
\hline Sh. flexneri & $\begin{array}{l}1 \\
5\end{array}$ & $\begin{array}{l}1 \\
4\end{array}$ & 9 & - & $\begin{array}{l}1 \\
6\end{array}$ & $\begin{array}{l}1 \\
2\end{array}$ & 8 & - & - & - & $\therefore$ & $\because$ & 20 & 16 & 10 & - & $\begin{array}{l}1 \\
4\end{array}$ & $\begin{array}{l}1 \\
1\end{array}$ & - & - & $\begin{array}{l}1 \\
8\end{array}$ & \begin{tabular}{l|l}
1 & 8 \\
3 & 8
\end{tabular} & - \\
\hline
\end{tabular}

$(-)$ Resistant 


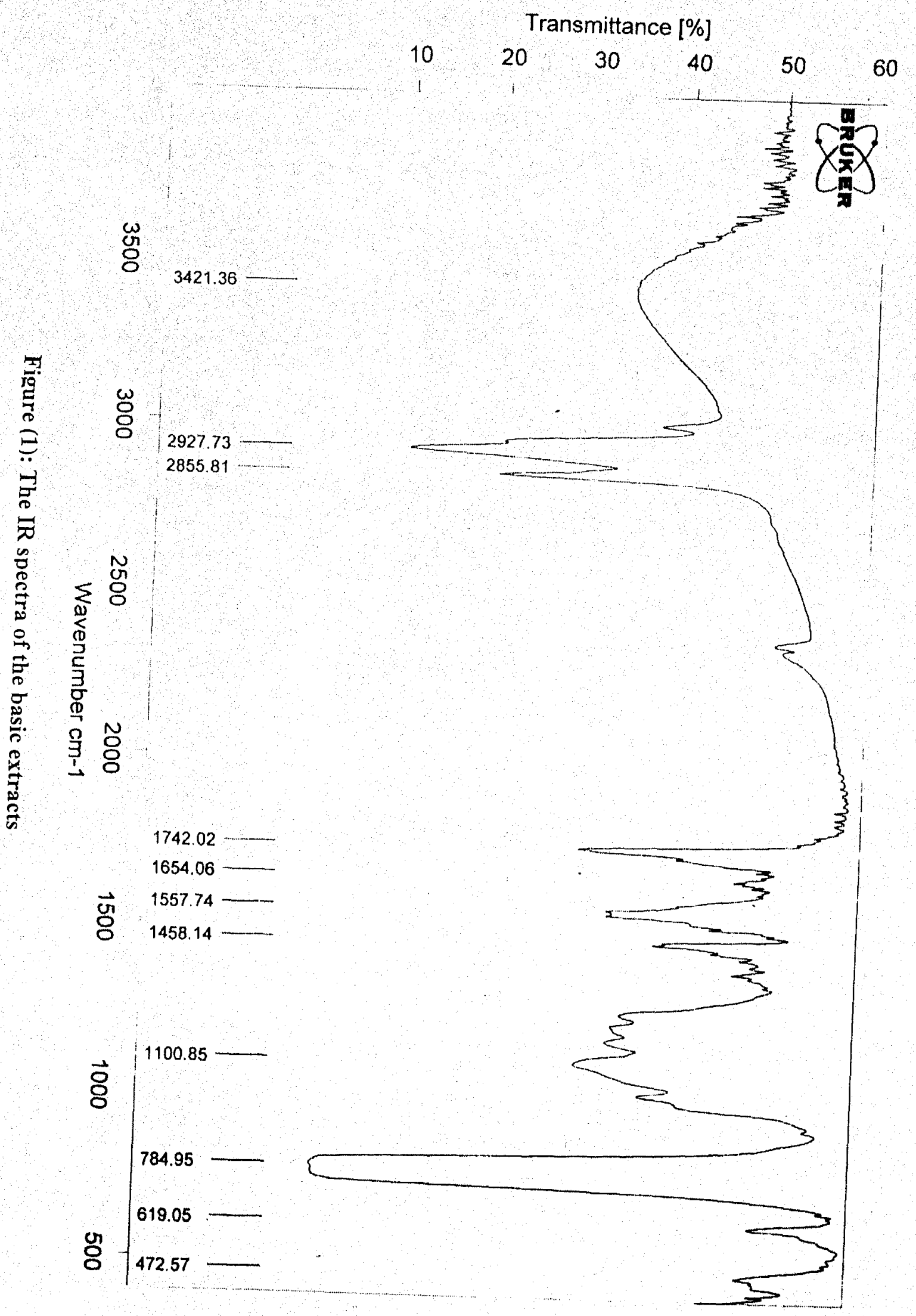




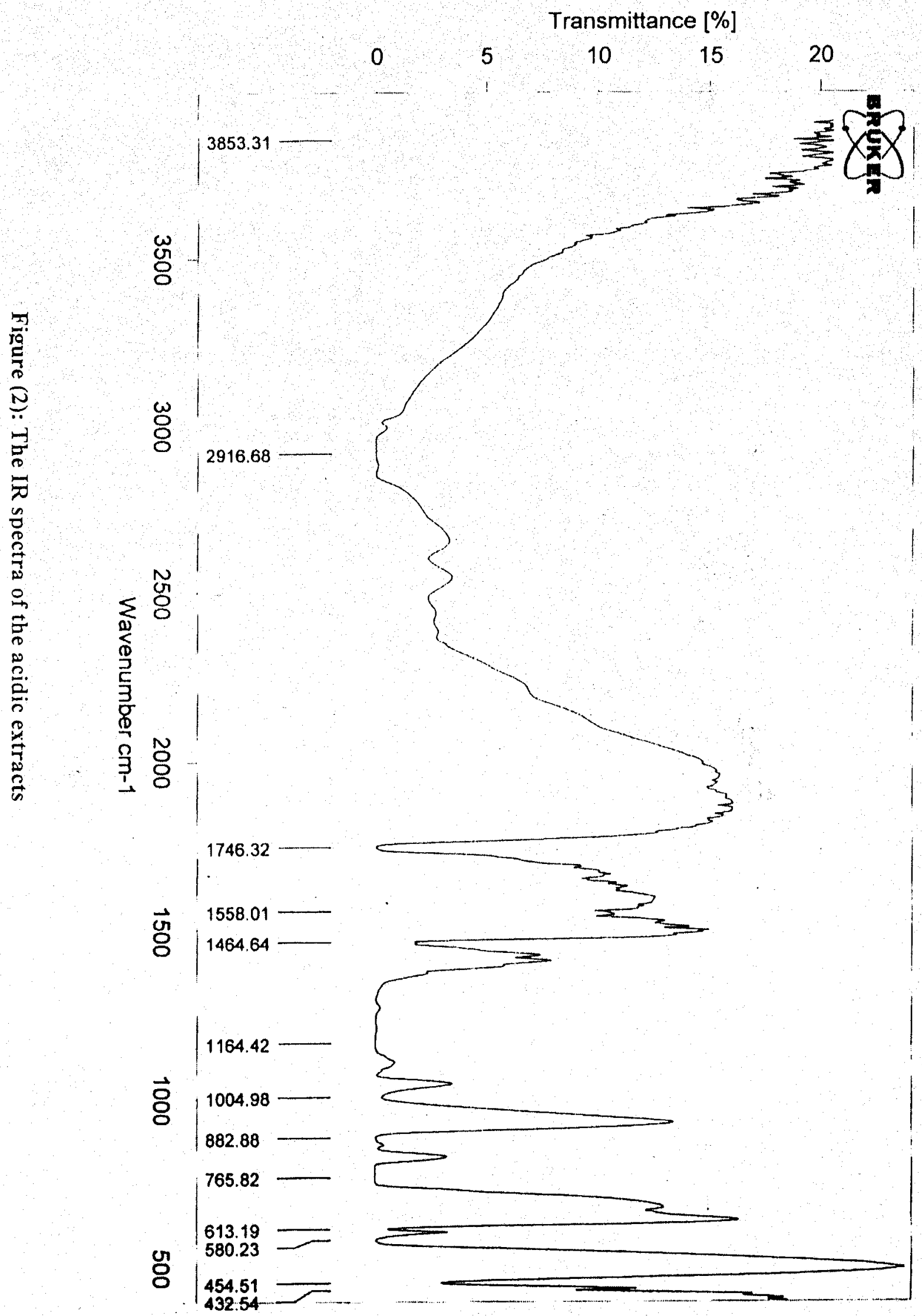




\section{REFERENCES}

1. Chevallier A. The Encyclopedia of Medicinal Plants. Dorlingkindersley Publishers, London, p. 237, 1996.

2. Brutis $M$. and Bucar F. Antioxidant activity of Nigella sativa essential oil. Phytother. Res., 14: 323-328, 2000.

3. Gilani A.H., Jabeen Q. and Khan M.A.U. A review of medicinal uses and pharmacological activities of Nigella sativa. Pak. J. Biol. Sci., 7(4): 441-451, 2004.

4. Fararh K.M., Atoji Y., Shimizu Y. and Takewaki T. Isulinotropic properties of Nigella sativa oil in streptozotocin plus nicotinamide diabetic hamster. Res. Vet. Sci., 73: 279-282, 2000.

5. El-Dakhakhny M., Mady N., Lember N. and Ammon H.P. The

- hypoglycemic effect of Nigella sativa oil is mediated by extra pancreatic actions. Planta Med., 68: 465-466, 2002.

6. Gilani A.H., Aziz N., Khurram I.M., Chuadhary K.S. and Iqbal A. Bronchodilator, spasmolytic and calcium antagonist activities of Nigella sativa seeds (Kalonji); a atraditional herbal product with multiple medicinal uses. J. Pak. Med. Assoc., 51: 115-120, 2001.

7. Boskabady M.H., Shirmohammadi B., Jandaghi P. and Kiani S. Possible mechanism(s) for the relaxant effect of aqueous and macerated extracts from Nigella sativa on tracheal chains of guinea pig. BMC Pharmacol., 4: 1-6, 2004.

8. Hanafy M.S. and Hatem M.E. Studies on the antimicrobial activity of Nigella sativa seed (black cumin). J. Ethnopharmacol., 34: 275278, 1991.

9. Khan M.A.L., Ashfaq M.K., Zuberi H.S., Mahmood M.S. and Gilani A.H. The in vivo antifungal activity of the aqueous extract from Nigella sativa seed. Phytother. Res., 17: 183-186, 2003.

10. Adday M.H., Rashan L.J. and Sulayman K.D. Antimicrobial activity of different extracts from the seeds of Peganum harmala. Fitoterapia., 4, 363, 1989.

11. Sulayman K.D. and Flayeh K.A. Antimicrobial activity of the amine fraction of the cucumber (cucumis sativus) extract. MIRCEN Journal, 3: 275-279, 1987.

12. Ahmad B.A., Sulayman K.D. and Aziz A.A. Antibacterial activity of the leaves of Nerium oleander. Fitoterapia., 3, 273-274, 1993.

13. Prescott L.M., Harley J.P. and Klein D.A. Microbiology. $3^{\text {rd }}$ ed. WCB, McGraw-Hill, Lowa, USA, 1996.

14. Khodair A.L., Hammouda F.A. and Abdel-Azim H. Phytochemical investigation of Thymus decassatus L. Qutar Univ. Sci. J., 13(2): 211-213, 1993. 
15. Harborne J.B. Phytochemical Methods. Halsted Press, John Wiley and Sons, New York, 1973.

16. Shriner R.L., Fuson R.C. and Grtin D.Y. The Systematic Identification of Organic Compounds. $5^{\text {th }}$ ed., John Wiley and Sons, Inc, New York, 1964.

17. Silverstein R.M., Bassler G.G. and Morrill T.C., Spectrometric Identification of Organic Compounds. $4^{\text {th }}$ ed., John Wiley and Sons, USA, 1981.

18. Ferdous A.J., Islam S.N., Ahsan M., Hasan C.M. and Ahmad Z.U., In vitro antibacterial activity of the volatile oil of Nigella sativa seeds against multiple drug-resistant isolates of Shigella species and isolates of vibrio cholorae and Escherichia coli. Phytotherapy Res., 6: $137-140,1992$.

19. Mashhadia N.V. and Rakhshandeh H., Antibacterial and antifungal effects of Nigella sativa extracts against Staph aureus, $P$, aeruginosa and C. albicans. Pak. J. Med. Sci., 21(1): 47-52, 2005.

20. Morsi N.M., Antimicrobial effect of crude extracts of Nigella sativa on multiple antibiotics resistant bacteria. Acta Microbiol. Pol., 49, 63-74, 2000.

21. El-Kamali H.J., Ahmad A.H., Mohammad A.S., Yahia A.A.M., ElTayeb $\mathrm{l}$, and $\Lambda$ li $\Lambda . \Lambda$., Antibacterial properties of essential oils from Nigella sativa seeds etc. Fitoterapia, 69: 77-78, 1998.

22. Sokmen A.B., Jones $M$. and Erturk $M$, The in vitro antibacterial activity of Turkish medicinal plant. J. Ethnopharmacol, 67: 79-86, 1999.

23. Anwar-ul H.G., Qaiser J. and Mohammad A.U.K., A review of medicinal uses and pharmacological activities of Nigella sativa seeds. Pakistan J. of Biological Sciences, 7(4): 441-451, 2004. 